\title{
Die kerkorde van die Nederduitse Gereformeerde Kerk 2013: Kanaal of hindernis vir kerklike tug?
}

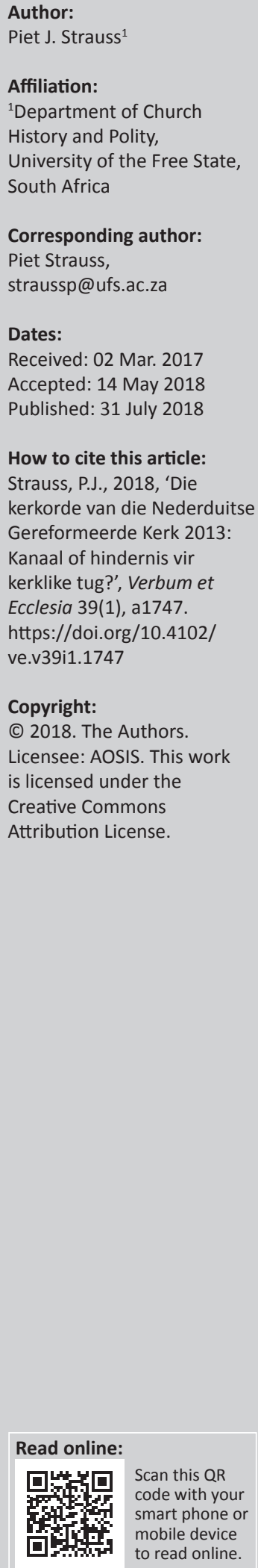

\begin{abstract}
The church order of the Dutch Reformed Church of 2013: Channel or stumbling block for church discipline? There is a widely accepted stand in reformed churches not to accept detailed prescriptions in its church order for church discipline. Church assemblies tasked with church discipline need space to undertake this according to God's Word, with a pastoral approach, the well-being of the church and its members in mind, and a good deal of common sense. Despite this, the Dutch Reformed Church accepted detailed rules and regulations for discipline as a binding addendum to its church order in 1974. This addendum was scrapped in 1998. However, a new addendum was again accepted in 2011. This article asks the question whether the binding articles and regulations of this church is a proper channel or a stumpling block for discipline in its midst.

Intradisciplinary and/or interdisciplinary implications: This article is based on a philosophical-sociological distinction between the discipline of the church as a society of faith and discipline in other institutions of society. The discipline of the church implies that the church is as an institution of faith, in this case, must also act according to the natural rules of justice and justice in terms of its own calling as an institution of the Christian faith. These rules and the church order as an instrument for procedure in the church, are the grounds on which a civil court, when asked to, can rehearse a decision of an assembly of the church. This is not about the merit of the church content of the decisions, but the procedure. The article also makes extensive use of ecclesiological matter or a dogmatic church concept that must be maintained in criminal matters. The challenge: the church remains theoretically and in practice church.
\end{abstract}

\section{Kerkorde en tug: Die probleem}

Gereformeerde kerkregtelikes beskou kerkordebepalings as kanale wat die regering van Christus in sy kerk as 'n regering deur, ten diepste, die Woord en Gees van God bevorder. ' $n$ Kerkorde moet slegs kanale of kernagtige ordereëlings daarstel waardeur die gesag en inhoud van die Skrif deur die kerklike lewe vloei. 'n Kerkorde moet die gehoorsaming van die Woord in die kerkpraktyk dien en 'n dienende orde gebou op kerkreg as 'n dienende reg wees (vir 'diens' in kerkordelike sin sien Bouwman 1985:596, die derde onveranderde druk waarvan die eerste druk reeds in 1928 verskyn; meer onlangs Plomp 1992:38-40; Koffeman 2009:90; Strauss 2009:494-495). 'n Kerkorde werk met toegepaste Skrif- en belydeniswaarhede sonder om hierdie Skrif òf belydeniswaarhede woordeliks te herhaal. Daarom verwys 'n kerkorde na sekere belydeniswaarhede - soos dat Christus as Hoof sy kerk deur sy Woord en Gees regeer (Jonker 1965:12) - wat rigting gee aan reëlings om die kerk te regeer (Plomp 1992:38-40; Strauss 2010:15).

Om 'n dienende orde te wees, moet ' $n$ kerkorde vir die kerk as 'n geloofs- en liefdesgemeenskap (Nederduitse Gereformeerde Kerkorde [NGKO] 2013:16) net algemene en duursame reëlings bevat. ' $n$ Kerkorde moet hom daarvan weerhou om die kerklike lewe in detail te reglementeer en die nakoming daarvan moenie ' $n$ doel op sigself, ' $n$ knypende wet of kru wettisisme word nie. ' $n$ Kerkorde as ' $n$ menslike dokument moenie die kerklike lewe in besonderhede reël en die deurwerking van die Woord van God in die kerklike praktyk smoor nie. Kerkordelike kanale moet Woordbepaalde ordekanale wees en nie dwingende, gedetailleerde wette van mense wat die laaste sê in die kerk het nie. Die eerste en die laaste sê kom die Woord alleen toe. In sy kerkorde moet die kerk slegs die ordelike regskante van sy bestaan as draer van die Woord reël. Die kerk moet 'n draer van die Woord wees en deur die geloofsbelang van sy lidmate, deur die beginsels én die toepassing van die Woord ${ }^{1}$ - nie menslike bepalings nie - gedryf word (Nauta 1971:13,14; Smit 1984:86).

1.Efesiërs 6:12 se swaard van die Gees. 
Bouwman oordeel dat ' $\mathrm{n}$ 'algemene' kerkorde of kerkorde vir 'n kerkverband - soos die Nederduitse Gereformeerde Kerk (NGK) met sy gemeentes - 'weinig (moet) bepaald en omschreven'. Dit moet gedoen word om 'formalisme' in die kiem te smoor en sodat 'Gods Woord zijn beslag op de harten niet verlieze'. Volgens hom moet 'n kerkorde erken dat Christus die Koning van sy kerk is en dat alles in die kerk daarom Woordgetrou moet wees. 'n Kerkorde moet uitgaan van die kernwaarheid dat Christusgesag Woordgesag is. Dat die Bybel die Woord van God en daarom van sy Seun Jesus Christus is. Volgens Bouwman moet ' $n$ kerkorde in diens van die Woord van God en die belydenis van die kerk ingestel wees op die goeie orde en welsyn van die kerk (Bouwman 1985:325-327). Op sy beurt bepleit Nauta, soos Calvyn, 'n kerkorde wat met sy bepalings afgestem is op die tyd en plek om die Woord en die sakramente te bedien, die tug uit te oefen en 'dergelijke'. Hierdie bepalings moet weerspannigheid, verwarring, woelinge en twiste in die kerk verhoed en betrek word op ritusse en seremonies, tug en vrede. Die kerkorde moet die kerk help om sy roeping te vervul, gehoorsaam aan die Here te lewe en alles tot sy eer te doen. Opgesom: die kerkorde is bloot kanale waardeur Christus sy kerk deur sy Woord en Gees regeer (Nauta 1971:13,14).

Vir die tema staan twee punte in hierdie betoog uit. Die eerste is dat die kerklike tug ' $n$ belangrike middel in die roepingsvervulling van die kerk as ' $n$ Godsgehoorsame geloofsgemeenskap is en die tweede dat kerkordelike bepalings oor die tug dieselfde rol moet speel as die kerkorde: dit moet die goeie orde en welsyn van die kerk bevorder. Anders gestel: kerkordelike bepalings en besluite oor die tug moet die orde en welsyn van die kerk as 'n Bybelse geloofsgemeenskap dien.

Teen hierdie agtergrond ondersoek hierdie artikel die vraag of die NG Kerkorde van 2013 (NGKO 2013) met sy bepalings in artikel 59-66 en reglement 18 oor die tug en dissipline aan die doel van ' $n$ gereformeerde kerkorde beantwoord? Sal die toepassing van dié bepalings die goeie orde en welsyn van die NGK bevorder?

Artikels 59-66 van NGKO 2013 (soos grootliks geformuleer in 1998) is in NGKO 2015 gehandhaaf. As sulks vorm dit steeds die bepalings van NGKO vir die kerklike opsig, tug en nou, dissipline. Wat wel in 2015 gewysig is, is die Reglement vir Tug en Dissipline (NGKO 2011, 2013 en 2015 Reglement 18) wat deur die Algemene Sinode van 2011 ingevoer is. Op enkele uitsonderings na volg Reglement 18 van 2015 dieselfde prinsipiële spoor as sy voorloper van 2011. Hoewel hierdie artikel op NGKO 2013 met sy bepalings en reglement vir die kerklike tug konsentreer, dui dit ook van die wysigings aan wat die beginsels van NGKO 1998 via NGKO 2011 in NGKO 2013 en 2015 en hulle reglemente ondergaan het. Die konsentrasie van hierdie artikel word egter in sy titel vervat.

\section{Kerklike tug Bybelsverantwoord}

Genoemde siening van die kerklike tug kom uit'n gereformeerde hoek en gebruik die tug as positief Bybels. So beskou is tug 'n liefdeshandeling wat die gehoorsaamheidsgehalte (en dus ook geloofs- en lewenseenheid) van die hele gemeente - deur die bank - in die oog het. 'n Benadering wat die drie merktekens van die ware kerk, naamlik die suiwere prediking van die Woord, die suiwere, Skrifmatige bediening van die sakramente en die handhawing van die 'kerklike tug ... om die sondes te straf', soos vervat in artikel 29 van die Nederlandse Geloofsbelydenis van 1561, insluit (NGK III 1982:29).

Hierteenoor verdedig Koffeman die houding van gereformeerdes in 'n kerklik plurale Nederland vir wie die amptelike kerklike tug tot 'n 'inhoudloze kerkordelijke aangelegenheid' (Koffeman 2009:282) verword het. Gelowiges wat hulle in ' $\mathrm{n}$ situasie bevind waarin etiese beslissings oor reg en verkeerd - soos oor die gay-kwessie aan die heersende kultuursituasie toegeskryf word. Vir hulle word die opvattinge in 'n sogenaamde moderne Christelike samelewing die maatstaf en nie eksplisiete, verantwoorde Bybelse vertrekpunte nie. In hierdie situasie word die kerklike tug negeer en nie as ' $n$ hulpmiddel vir die roepingsvervulling van die kerk beskou nie. Anders as die Nederlandse Geloofsbelydenis beskou Koffemans die 'handhaving van de kerklijke tucht' nie as 'n kernmaatstaf vir 'n 'kwaliteit'-gemeente nie. Pastorale sorg, medemenslikheid en 'n ongekwalifiseerde morele vorming is syns insiens meer in die kol (Koffeman 2009:282). ${ }^{2}$

Hier is egter 'n groot misverstand. Talle moderne handhawers van die kerklike tug wil juis pastoraal, medemenslik en moraalvormend tot behoud van diegene wat getug word, optree (Strauss 2010:110). Daarom noem Bouwman die regte kerklike tug 'persoonlijk en amptelijk' (Bouwman 1985:599). Hierdie persoonlike hantering van die kerklike tug gaan gepaard met respek vir die medemens wat na die Beeld van God geskep is en met Skriftuurlike medemenslikheid.

Natuurlik moet daar begrip vir weerstand teen die verkeerde gebruik van die kerklike tug wees. Die toets vir die voortsetting van die kerklike tug al dan nie kan egter nie die verkeerde gebruik daarvan deur kerkmense wees nie. Immers: alles waaraan hierdie sondaars vat, kan lelik word. Om Maarten Luther op te haal: op sy beste is die gelowige ' $n$ verloste (begenadigde) sondaar, nie 'n sondelose verloste nie (Luther se simul justus ac peccator - 'n geregverdigde, vrygespreekte sondaar [De Jong 1987:170]). Moet alles 
waarvan sondige mense karikature maak, dan afgeskaf word? Moet ons ete en drinke vanweë brassery en dronkenskap verban word?

Hierteenoor praat die Bybel as die norm van die norme (norma normans) vir gereformeerdes, van tug 'omdat God ... julle liefhet' en 'ons in sy heiligheid mag deel' (Spr 3:12; Heb 12:10). Daarom rig die Skrif die kerklike tug op die gehoorsaamheid en geloofskwaliteit van die kerk. Die kerklike tughandeling is ' $n$ Bybelse konstante wat nie verval in ' $n$ nuwe tyd nie. Die menseregtegeoriënteerde mens, in die Westerse sin van die Woord en in die greep van 'n relativerende post-modernisme hier in die 21ste eeu, is juis antitug, antivoorskriftelik en antigesag ingestel. Bybelse waarhede raak egter nie ongeldig in nuwe kultuursituasie nie (vgl. Strauss 2001:398-400, 2008a:242, 2010:109).

Die groot vraag is nou: gee Kerkorde 2013 (of dan NGKO 2013) aan die NGK die ruimte om die tug medemenslik, moreelvormend en getrou aansy aard as'ngeloofsgemeenskap toe te pas?

\section{Nederduitse Gereformeerde Kerkorde: Probleme oor 'kerkorde en tugbepalings'}

Met hierdie omskrywing van die prinsipiële aard van 'n kerkorde, het die Algemene Sinode van die NGK wat sedert 1962 bestaan én op sy kerkorde besluit, die afgelope meer as 50 jaar nie deurgaans vrede gehad nie. Inteendeel, afgesien van sy wisselende bepalings oor die kerklike tug, illustreer die feit dat die NGKO skipper tussen geen reglement nie en 'n reglement vir die kerklike tug, hierdie punt. Hierteenoor het 'n vergelykbare gereformeerde kerk soos die Gereformeerde Kerke van Suid-Afrika (GKSA) in hulle kerkorde, wat meer direk as die NGKO in die verlengde van die Dordtse Kerkorde (DKO) van 1619 lê, ' 'n groter stabiliteit en konsensus gehad (Kruger et al. 1966:42; Van der Linde 1983:x-xi). In die GKSA moet lede van kerkvergaderings ook ' $\mathrm{n}$ 'Openlike Verklaring' onderskryf waarin hulle onderneem om die regering van die kerk aan die hand van die DKO 1619, soos gewysig in nuwe omstandighede deur sinodes van die GKSA, voort te sit (Visser 1999:2).

Die eerste NGKO, naamlik NGKO 1962, het slegs 'nadere' artikels oor die kerklike tug bevat (NGKO 1964:12-14). Jonker beskou die benadering van NGKO 1962 in 1960 as gereformeerd. Hy oordeel dat hierdie dokument 'die hele kerklike lewe' probeer 'orden deur enkele groot lyne te trek waarin ... [die NGK] in vryheid en verantwoordelikheid met die Bybel in die hand mag beweeg' (Jonker 1960:36). Jonker soek Woordgesag omdat Woordgesag Christus as die Hoof van die kerk erken - ook in die NGK se hantering van die tug. Hy is intens bedag op ' $\mathrm{n}$ reglementering van die kerklike lewe of 'n verduistering van die Woord deur - te veel menslike bepalings.

Hierdie situasie in NGKO sou egter in 1974 verander.

Sadler, wat 'n grondige, omvattende studie van die tughandeling in die NGK gemaak het, skryf die aanvaarding deur die Algemene Sinode van 1974 van 'n ‘Reglement vir die uitoefening van die tug en die beslegting van geskille' (NGKO 1974:46-58) aan verskeie faktore toe. Volgens hom is ' $\mathrm{n}$ belangrike een die reglementeringswoede of -heerskappy wat destyds in die NGK merkbaar was - 'n woede wat wou sorg vir 'n stap-vir-stap handleiding en eenvormigheid in die gebruik van die tug in die NGK. In die reglement van 'n stewige 22 bladsye is hierdie woede sigbaar (Sadler 1979:3334). Voorbeelde is die gedetailleerde lengte daarvan, 'n skoolse herhaling van die reëls vir die wettiging van kerkvergaderings wat by die kerkraad, ring en sinode voorkom en 'n verbod op die sitting van partye in die kerkvergadering wat die tugsaak hanteer: die reglement herhaal dié verbod woordeliks vir die kerkraad, die ring en die sinode. Daarby kommunikeer niekerklike begrippe in die reglement, soos die 'verhoor' in 'n tugsaak, juridiese klanke wat met die kerklike tug as ' $n$ kerklik-pastorale handeling stry. Die Reglement van 1974 eindig met ' $n$ siellose soort vormgodsdiens deur middel van 'n voorgeskrewe, gedetailleerde vorm vir die indien van klagtes (NGKO 1974:46-58).

Weens 'n gebrek aan amptelike kerklike bronne word Sadler se redes vir die NGK se Tugreglement van 1974 hier gebruik. Hy was immers 'n oor- en ooggetuie daarvan (vgl. Sadler 1979: voorwoord). Volgens hom was een van die redes vir dié reglement 'n gebrek aan duidelike reëls. Dit sou aanleiding gee tot onsekerheid en willekeur in die tughandeling. Daarby moes kerklike tugsake van burgerregtelike begrippe soos 'verhoor' en 'prosedeer' gesuiwer word ${ }^{5}$. Die antwoord van die Algemene Sinode van die NGK in 1974 hierop was: 'n reglementering (reël op reël) van die tug (Sadler 1979:30-32).

Hierteenoor beklemtoon Sadler by herhaling: die tug kan sy kerklike karakter alleen behou deur 'n studie en verdieping van die aard daarvan, eerder as 'n reglementering daarvan (Sadler 1979:3,31).

Sadler wys daarop dat die gebruik van ' $n$ tugreglement in die NGK herinner aan die eerste Algemene én Tugreglement van die eerste NGK-sinode, die 'Algemeene Synode' van 1824 in Kaapstad (NGK 1857:I; Sadler 1979:32). Hierdie vergadering het nie die gereformeerde lyn van Dordtrecht soos gehandhaaf by die Nederlandse gereformeerde sinodes vanaf 1568 tot 1619 met die DKO 1619 as kulminasiepunt (Rutgers 1971; Pont 1981:55-189) - om 'n kerkorde op te stel nie, maar die 'vigerende' Kaapse NGK-Kerkorde

4.By die bestaande bepalings van twee en $n$ half bladsye in NGKO word ' $n$ reglement van 22 bladsye gevoeg (NGKO 1962:12-14, 1974:13-16, 46-58).

5.NGKO 1962 en NGKO 1970, wat sonder ' $n$ tugreglement funksioneer, bevat nie hierdie soort burgerregtelike terme nie (NGKO 1962:2-14, 1970:14-17). Moontlik wou die tugreglement van 1974 die gebruik van hierdie terme in die praktyk van die NGK stop. Die woord 'verhoor' het egter deurgeglip ... 
van De Mist van 1804 en die Algemene Reglement van 1816 van die Nederlandse Hervormde Kerk - 'n algemene reglement met ' $n$ tugreglement (NGK 1857:7). Die name 'Algemene én Tugreglement' by die NGK van 1824 openbaar reeds ' $n$ kerkhistoriese én geestelike verwantskap met die 'Hervormde' Kerk én rigting in Nederland. In die Nederland van 1816 is van die 'Reglement op de Uitoefening van kerklijke Opzicht en Tucht' gepraat - 'n bewoording wat die NGK in 1824 oorneem (Pont 1991:224; Sadler 1979:8,32) en by sy Algemene Sinode van 1974 steeds weerklank vind (NGKO 1974:46). ${ }^{6}$ 'n Verwantskap wat die ooreenkomste tussen die Reglemente van 1816 (Nederlands Hervormde Kerk) en 1824 (NGK) help verklaar sonder om die verskille deur sommige aangetoon, te ignoreer (Kleynhans s.a.:123-129; Sadler 1979:32). Met die aanvaarding van die Algemene én Tugreglement van 1824 het die NGK kerkordelik van rigting verander omdat hy sy bewese gehegtheid aan die DKO en sy gereformeerd kerkregtelike onderbou (vgl. Vorster 1960:13) vir ' $n$ kollegialistiese verenigingsreg verruil het (Kleynhans s.a.:119; Koffeman 2009:12; Strauss 2008b:275-276).

Daar is gewys op Jonker se oordeel dat NGKO 1962 weer op die gereformeerde spoor gekom het. Sadler beweer dat die tugreglement van 1974 'n afbuiging van hierdie spoor was (Sadler 1979:32). Van 1962 tot 1974 - vir twaalf jaar lank - het die NGK sonder 'n tugreglement klaargekom. Waarom nou 'n reglement met sy reglementerende neiging invoer? Hierdie reglement word in 1998 geskrap net om in 2011 met 'n nuwe reglement vervang te word. Hoekom dié onstabiliteit en inkonsekwentheid by die NGK in sy kerkordes en die kerkordelike hantering van die tug? Daarby: wat presies hou hierdie verandering in die NGK kerkordelik in?

\section{Geen reglementering}

Sadler toon dat die 'gereformeerde kerkreg' afwysend staan teenoor enige reglementering van die kerkreg en die 'kerklike tughandeling'. 'n Tugreglement is vreemd aan gereformeerde kerke (Sadler 1979:32). Hy wys op die vermaarde gereformeerde kanonikus, F.L. Rutgers, wat aanvoer dat die doel van die kerklike tug - kortweg die eer van God, heil van die kerk en behoud van die sondaar - 'de grootste speelruimte in de toepassing, geen regelen voor vaste practijk' vereis. Indien die Bybelse 'beginselen' vir die tug toegepas word, word die tug reg hanteer. Die kerkorde moenie ' $n$ wet word wat hierdie speelruimte bedreig nie. Volgens Sadler moet daar in die tughandeling "n hoë mate van soepelheid en aanpasbaarheid wees'. Veral as dit gaan oor 'die tyd en omstandighede waarin die tug toegepas word' (Sadler 1979:30-31). Die gereformeerde 'vaders' was daarvan oortuig dat hulle nie weer 'n 'boekdeel met reglementen' moet aanvaar en daardeur aan iets soos die Roomse Corpus Iuris Canonici ruimte bied nie (Sadler 1979:34).

Saamgevat: vir die kerklike tughandeling is daar die norme van 'n Bybelse regverdigheid (die gebruik van die gemeenregtelike reëls van natuurlike geregtigheid wat ook vir niestaatlike kwasijudisiële sake soos kerklike tugsake geld, sluit hierby aan NGKO 2013; Sadler 1979:51; Strauss 2010:112), egte broederliefde (wat versoenend is sonder om skuld te verdoesel of billikheid van weerloses te weerhou), konsekwentheid (met Skrifgetrouheid as 'n lewenshouding) en ' $n$ herderlike benadering. Die behoud van die sondaar en van die kerk as 'n gemeenskap van Godsgehoorsames moenie deur 'n onkerklike wetlike prosedure verydel word nie. Sadler wys op Plomp - laasgenoemde dui nie 'n primêre bron aan nie - wat aantoon dat Calvyn ook ' $n$ 'dosis' lewenswysheid of psigologiese insig as kernelemente by die kerklike tughandeling betrek het (Plomp 1969:163; Sadler 1979:31).

Dit is so dat die artikels van die kerkorde in die NGK die goedkeuring van ' $n$ tweederde meerderheid van die Algemene Sinode (NGKO 2013:12) vereis en dat 'n reglement 'n blote meerderheid vra. Laasgenoemde word vir afhandeling deesdae ook na sinodale kommissies verwys. ${ }^{7}$ Dit beteken dat die reglemente ondergeskik is aan die artikels van die kerkorde en dat die kerkorde voorrang geniet in geval van 'n botsing. Maar as besluite van die Algemene Sinode bly albei bindend in die NGK en word dit deur die burgerlike howe saam met die reëls van natuurlike geregtigheid beskou as die NGK se aanvaarde 'prosedure' (vir 'n meer genuanseerde uiteensetting kyk Sadler 1979:176-179).

In beginsel sou mens kon aanvoer dat die kerkordes van gereformeerde kerke én kerke wat 'n tugreglement vir die tughandeling gebruik, geen reglementering moet toelaat nie. Dit is nie die blote bestaan van ' $n$ reglement - of kerkorde - wat die kerklike tughandeling reglementeer en die soepelheid en lewenswysheid van die tugliggaam kortwiek nie, maar die inhoud daarvan. Teen hulle historiese agtergrond beskou, neig reglemente om te reglementeer, maar dit hoef nie ...

\section{Die Nederduitse Gereformeerde Kerkorde 2011: Weer 'n reglement}

Met die skrapping van sy tugreglement in 1998 het die Algemene Sinode van die NGK waarskynlik die weg vir 'n tughandeling met duursame reëls of vertrekpunte probeer baan. Reëls sonder knellende, beperkende voorskrifte wat die speelruimte vir lewenswysheid, psigologiese insig en ' $n$ pastorale aanpak strem. Daar is geen amptelike verslag of skriftelike getuienis om te bepaal of hierdie reglementlose kerkordelike benadering van 1998-2011 suksesvol was en tot ' $n$ verdiepte verstaan en opskerping van die tug in die NGK gelei het nie. Daar is ook nie 'n verslag of notule wat aandui of NGKO 1998 artikels 59 tot 66 oor die 'kerklike opsig en tug' ten opsigte van tugprosedure so ontoereikend was dat hersienings deur die burgelike hof van kerklike beslissings in dié tyd meer voorgekom het nie (NGKO 2007:24-30, 2011:17-20; NGKO VS 1998:44-53).

7.Die skrywer het ervaring van hierdie handelswyse. Dit gebeur soms omdat sekere reglemente nie noodwendig in die breë, algemene NGK-belang is nie en sekere kommissies met spesialiswerk besig is. 
'n Poging om die regte tugprosedure - teenoor die howe - te verseker deur sinodale tugtribunale of onkerklike 'howe' in te voer, was in hierdie tyd nie op algemene sinodale vlak in die NGK suksesvol nie (Strauss 2010:113).

In 1998 het die NGK verkleinde tugliggame of 'gevolmagtigdes' met afhandelingsbevoegdheid, soos deur kerkrade, ringe en sinodes in hulle plek benoem, moontlik gemaak (NGKO VS 1999:46). Liggame waarop die betrokke kerkraad, ring of sinode in ' $n$ meerderheid verteenwoordig was, maar waarop regslui, kerkregtelikes én ander 'wyses', soms van buite die vergadering, ook benoem kon word. Vanweë my persoonlike betrokkenheid by die dosering van kerkreg aan ' $n$ NGKerkende teologiese fakulteit, is ek ook van tyd tot tyd by sulke liggame betrek. My ervaring was dat 'n kerklik-pastorale inslag en ' $n$ sensitiwiteit vir die regte prosedure telkens geseëvier het. Nie een van hierdie sake is in 'n burgerlike hof hersien nie (Strauss 2010:113). Daarby het nuwe begrippe in NGKO1998 soos die kerk as 'n 'geloofs- en liefdesgemeenskap', tug met 'n 'geestelike karakter' en 'geestelike middele' en kerklike opsig en tug as ' $n$ 'pastoraal-kerkregtelike' handeling wat uit ' $n$ Bybelse en geestelike oogpunt billik en regverdig' moet wees, ' $n$ tipies kerklike koers aan tug in die NGK gegee (NGKO VS 1998:45)

Daar is geen verslag of motivering in notules waarop ek my hande kon lê oor waarom die Algemene Sinode in 2011 besluit het om, teen die gereformeerde tradisie in, weer ' $n$ tugreglement vir die NGK te skep nie. Daar is ook geen aanduiding of artikels 59 tot 66 van NGKO 2011 vir hulle internkerklike werking eers aan 'n grondige evaluering onderwerp is nie (NGKO 2011:17-20). Geen aanduiding dat die NGK op hierdie punt om ernstige redes van ander gereformeerde kerke verskil ('n tema vir gesprekke met gereformeerde kerke binne die een, heilige, algemene, Christelike kerk) en dat die Algemene Sinode besef dat hy hier 'n gewigtige besluit neem nie.

Volgens die skriba van die Algemene Taakspan Regte (ATR) van die Algemene Sinode, Helgaard van Rensburg, was die rede vir die herinstelling van ' $\mathrm{n}$ tugreglement iets anders. Terwyl bogenoemde kwessies - ook die mening van gereformeerdes buite die NGK en gereformeerde kerke met wie die NGK ekumene bedryf - geen rol gespeel het nie, het die Taakspan geoordeel dat NGKO in sy kerkorde-artikels die beginsels van die saak stel, terwyl daar ' $n$ reglement vir die uitvoering van die tughandeling moet wees $(H$. van Rensburg, persoonlike onderhoud, 17 Januarie 2017).

Dit wil voorkom asof die siening van 'n gereformeerde kerkorde as praktiese kanale vir die deurvloei en uitvoering van die Woord van God in die kerk nie verreken is nie. Immers, gereformeerd-kerklik gee Skrif en belydenis, en nie die kerkorde nie, die 'beginsels' vir die kerk se lewe en die kerkorde die ordelike, praktiese kanale vir die regering van

8.Dit was telkens ' $n$ diep geestelike ervaring om ervare 'regsmense' as kerklidmate se pastorale en kerklike impak op kerklike tugliggame te ervaar. Jarelange ondervinding op die regbank kweek ook ' $n$ gesonde dosis mensekennis gepaar met ' $n$ aanvoeling vir 'natuurlike geregtigheid' by gelowige, sensitiewe regters.
Christus deur sy Woord en Gees. Die kerkorde skep dus ordelike kanale vir die optrede/praktyk van die kerk. Daarom dek die hoofstukke van die meeste kerkordes die hele kerklike lewe (kyk NGKO 2013:1-20). ${ }^{9}$ Met sy 'nuwe' onderskeiding van kerkorde (beginsel) en reglement (uitvoering) kompliseer die Algemene Sinode van $2011^{10}$ die saak.

In een opsig moet die Taakspan - hoewel hy die argument nie gebruik nie - gelyk gegee word. Die invoering van 'n reglement per se hoef nie die tug in die NGK te reglementeer nie. 'n Reglementering of verjuridisering met detailvoorskrifte vloei nie noodwendig uit die blote bestaan van 'n reglement nie, maar uit dit wat die reglement bepaal. Daarom moet NGKO 2013 met sy artikels oor die kerklike opsig en tug (artikel 59-66) én reglement 18 oor tug en dissipline nou ondersoek word (NGKO 2013:15-19, 73-77).

\section{Nederduitse Gereformeerde Kerkorde 2013 tug en dissipline}

Artikels 59 tot 66 van NGKO 2013 vervang artikels 58 tot 64 van NGKO 1998 (NGKO 1998:20-25, 2013:15-19). Die kern van NGKO 1998 word in NGKO 2013 gehandhaaf in sake soos die aard en doel van die tughandeling, tugmaatreëls en die voorwaardes vir die opheffing van hierdie maatreëls. Die bewoording van NGKO 2013 artikel 59 tot 66 is in 'n groot mate dieselfde as dié van NGKO 1998 artikel 58 tot 64 . NGKO 2013 oor die kerklike tug - soos NGKO 1998 - bly dus breedweg by kernsake of algemene, duursame reëlings. Wat in NGKO 2013 bygevoeg word, is die dissipline van persone wat met ' $n$ dienskontrak in ' $n$ diensverhouding met ' $n$ kerk of gemeente of met die verband van NGK-gemeentes staan. Hierdie saak word in 'n nuwe artikel 63 opgeneem (NGKO 2013:17).

Wat op hulle beurt deur NGKO 2011 en 2013 uit NGKO geneem en tot ' $n$ uitgebreide reglement van vier bladsye vermeerder word - in NGKO 2015 brei die betrokke reglement uit na meer as vyf bladyse (NGKO 2015:81-86) - is bepalings oor die samestelling van tugliggame, die aanbring van 'n klag, ' $n$ nadelige gerug of ' $n$ nadelige verslag oor amptelike kerklike werksaamhede en die verloop en afloop van die ondersoek. Die reglement probeer oënskynlik om op 'n uitgebreide wyse voorskrifte te bied vir die uitvoering van die tughandeling in die NGK én te verseker dat dit korrek toegepas word. Hoewel die rede vir die verandering die ongeldige onderskeid tussen die beginsel of kerkorde en sy uitvoering deur die reglement was, wou die reglement skynbaar ook die tugbepalings van NGKO 1998 met sy 'speelruimte' aan tugliggame nader reël omdat hierdie liggame volgens die vermoede van die voorstanders van NGKO 2011, 2013 en 2015 nie kundig genoeg was om dit reg te gebruik nie. Daarom is kerkorde-artikels of kanale oor die

9. Hierdie temas of hoofstukke is agtereenvolgens: die belydenis, aard en orde van die NGK, die ampte, vergaderings, arbeid, opsig en tug en betrekkinge van die kerk na buite (NGKO 2013:v,vi).

10.'n Onwetendheid wat sy oorsprong waarskynlik by die betrokke taakspan, die ATR, het - ' $n$ taakspan wat die reglement aan die Sinode voorlê skynbaar sonder om die saak breër te motiveer of toe te lig, sonder om die saak in sy historiese en gereformeerd-ekumeniese konteks te plaas. 
uitvoering van die tughandeling vermeerder tot die meer gedetailleerde voorskrifte van Reglement 18: die Reglement vir tug en dissipline.

Die opneem van hierdie soort dissipline in NGKO 2013 en Reglement 18 skep egter vrae.

Die 'formele' dienskontrakte vir dominees en kerklike amptenare wat die NGK se 'internkerklike' antwoord in 1998 op nuwe arbeidswetgewing in Suid-Afrika was (NGKO 1994:2-5, 1998:2-9), het nou tot in tugsake deurgewerk. Dissiplinêre sake teen amptenare wat normaalweg meer formeel juridies aan die hand van hulle dienskontrak verloop en tot die beëindiging van hierdie kontrak kan lei, het nou 'n aparte punt onder die tug geword. Vanuit 'n kerklike oogpunt kom die vraag egter: kan die kerk in 'dissiplinêre' gevalle (tuggevalle?) ' $n$ ander baadjie as 'n kerklike baadjie ('n liefdes- en geloofsbaadjie) aantrek? Is kerklike dissiplinering iets anders as kerklike tug? Moet alle tug- of dissiplinêre sake kerklik beskou nie volg op die moontlikheid van 'sondes wat openbare aanstoot gee' (NGKO 2013:16 art 61) nie? Kan jy oortredings uitsonder en by name noem asof dit nie onder die algemene norm van sondes wat openbare aanstoot gee, val nie? ${ }^{11}$ Is die bedoeling van die uitdrukking 'sondes wat openbare aanstoot gee' nie om alle gevalle te dek nie? Is dit nie die rede waarom NGKO artikel 60.1 bepaal dat die kerklike opsig en tug oor die hele 'lewenswandel (leer en lewe)' van al die lidmate van die gemeente gaan nie (NGKO 2013:16)? Die verontagsaming of diskreditering van 'n kerklike dienskontrak deur 'n lidmaat kan ook uit 'n sonde wat openbare aanstoot gee, spruit. Wat meer is: die wyse van die verontagsaming van die dienskontrak kan òò openbare aanstoot gee. Aan die ander kant kan die nie-nakoming van 'n kontrak uit redes spruit wat nie openbare aanstoot gee nie. ${ }^{12}$ Dan is dit nie ' $n$ tugwaardige sonde nie en tree die bepalings van die dienskontrak of ' $\mathrm{n}$ 'normale' kerklike hopelik - oplossing in werking.

NGKO 2013 artikel 61 oor die aard van tugwaardige sondes as sondes wat openbare aanstoot gee, staan in die verband van artikels 59 tot 66 en dien as ' $n$ inleiding vir die tugtiging en, sedert 2011, dissiplinering van 'kerkmense'. Moet dissipline in die werkplek om genoemde redes nie op 'n ander vlak as die tug hanteer word nie, hoewel sekere voorvalle rondom ' $\mathrm{n}$ diensverhouding wel openbare aanstoot kan gee en tugwaardig kan wees? Waarom kan die reëls vir die kerklike tug nie kerklik bly en toegepas word nie? Die kerk hoef nie te spring vir elke verandering in die arbeidswetgewing van die staat nie. Daarvoor bestaan daar geloofsvryheid in Suid-Afrika en 'n breë besef van die eie aard van die kerk. Boonop is die 'bedryfsposte' van kerklike amptenare nie 'n saak wat primêr - in die eerste plek - aan tipiese kerklike geloofsbeginsels gemeet

11.NGKO 2013 sonder wel ergerlike sondes soos owerspel, onsedelikheid, egskeiding moord, meineed, diefstal en leerdwaling uit vir predikante wat ná sulke gedrag moord, met sy of haar geloofwaardigheid as evangeliedienaar in die kerk (NGKO 2013:19).

12.Indien die betrokke amptenaar nie ' $n$ lidmaat van die gemeente of ' $n$ gemeente in kerkverband is nie, is tug of dissiplinering na aanleiding van openbare ergerlike gedrag 'n moeilike saak. word nie, maar aan hulle administratiewe, koste- en tydsdoeltreffendheid. Hierdie soort doeltreffendheid is ' $\mathrm{n}$ belangrike administratiewe steunpunt vir tipies kerklike geloofswerk, maar vervang of maak dit nie vanself geloofsdoeltreffend nie. Boonop het NGKO 1998 artikel 12 in sy kerklike omskrywing van 'diensverhoudinge' en 'diensooreenkomste' die arbeidswetgewing in Suid-Afrika met goeie gevolge verkerklik (NGKO 1998:4-8).

\section{Nederduitse Gereformeerde Kerkorde 2013 en die nuwe Tugregelement}

Hierdie artikel het reeds op die wenslikheid al dan nie van 'n tugreglement gewys. 'n Belangrike punt is dat 'n reglement per se nie hoef te reglementeer nie. Reglementering hang van die inhoud van die reglement af of dit wat die reglement bepaal. Daarom moet die inhoud van Reglement 18 van NGKO 2013 ondersoek word. Dit word gevolg deur die beloofde ondersoek na NGKO artikel 59 tot 66 .

Die Algemene Sinode van 1998 het met die afskaffing van die Tugreglement van 1974 'n nuwe koers ingeslaan. Tug moes deur die NGK as 'n liefdes- en geloofsgemeenskap uitgeoefen word en die kernagtige kerkordelike bepalings daarvoor ruimte gee vir 'n speelruimte van lewenswysheid en 'n pastorale aanvoeling by die toepassers. Tughandelinge moes die geïmpliseerdes trek en bind en nie wegstoot nie. Kerklike tug moes vanuit die omgeehart van die gemeenskap van gelowiges kom. As ' $n$ uitgesproke gereformeerde kerk - dit word vervat in sy naam - wou die NGK in sy tug reformeer met die houding van 'ecclesia reformata semper reformanda' (dit is van ' $\mathrm{n}$ gereformeerde kerk om altyd te reformeer [Koffeman 2009:35]).

Die Sinode van 1998 het egter ook besef dat tugliggame in die NGK, naamlik die vergaderings van die kerk (kerkraad, ring, sinode) of hulle aangewese gevolmagtigde kommissies, in 'n oorgangstyd van die uitgebreide reglement van 1974 tot die kernagtige bepalings van 1998, oorbrugging nodig het. 'n Oorbrugging van tydelike maatreëls om onkunde en onsekerheid te verminder, maar ook 'n speelruimte vir lewenswysheid en pastoraat te laat. Daarom is daar by die artikels oor die kerklike tug in NGKO 1998 'n aantal besluite gevoeg - met minder duursaamheid en gewig as die artikels wat op die praktyk van die tughandeling konsentreer. So handel NGKO 1998 artikel 59 besluit 59b oor die benadering van tugondersoeke en artikel 61 besluit $61 \mathrm{~b}$ oor die vasstelling van die beweerde sonde, die samestelling van die tugliggaam, die stuiting in die amp vir die duur van die ondersoek en die prosedure tydens so 'n ondersoek (NGKO 1998:20-23). Besluite wat nie die gesag van kerkorde-artikels het nie en daaraan ondergeskik is. Besluite wat van tyd tot tyd, met die moontlike verdieping van die tug in die NGK, hersien en geskrap kan word. Geskrap word sodat kerklike tugliggame - in die woorde van Jonker - met die Bybel in die hand en met kernagtige ordereëls, hulle funksie moet vervul. Dit is opvallend dat hierdie besluite konsentreer op die uitvoering van die tughandeling op die behoefte aan duidelikheid wat nou in die NGK ontstaan het. 
Om een of ander rede ${ }^{13}$ is hierdie besluite, naamlik $59 \mathrm{~b}$ en 61b, in NGKO 2002, 2004 en 2007 (NGKO 2002:24-27, 2004:25-29, 2007:25-28) as uitgebreide, onnatuurlik breë subartikels in die betrokke kerkorde-artikels ingetrek. Dit het onmiddellik meer gedetailleerde bepalings geskep en die karakter van NGKO nog 'n keer verander. NGKO 1998 se oogmerk van oorbrugging het 'n stille dood gesterf.

Die Algemene Sinode van 2011 is met hierdie uitgroeisel gekonfronteer.

Sy Taakspan Regte wou die NGKO dalk gereformeerd kerkordelik inrig met kernsake en het daarom die onderskeid tussen ' $n$ kerkorde as die beginsel en reglement as die uitvoering daarvan ingevoer. Die inhoud van die besluite van NGKO 1998 is uitgebreid verwoord in die Tugreglement.

Globaal beskou het die oorgrootte meerderheid van die bepalings van Reglement 18 van NGKO 2013 egter meriete. Dit bou op die besluite van 1998 en geld as tydelike oorbruggingsmaatreëls. Dit is immers ook hier waar die probleem van 1998 gelê het: by die praktyk van die tughandeling in die NGK.

'n Ondersoek na die tughandeling in die NGK van 1998-2011 gaan egter mank aan ' $n$ behoorlike verslag oor die verloop van hierdie handeling aan die hand van NGKO 1998. 'n Goeie evaluering van die saak kan alleen op 'n goed begronde gevallestudie volg. Daarby bevat Reglement 18 meer as net maatreëls vir oorbrugging. In sommige van die bepalings weerklink die gemeenregtelike situasie in Suid-Afrika. Reglement 18 is nie vry van die juridiese angels van 1974 nie.

In punt 8.1.1 word iemand met ' $\mathrm{n}$ botsende belang by die saak wat ondersoek word, van sitting op die betrokke NGKtugliggaam weerhou (NGKO 2013:76). Hierdie botsende belang klink na dieselfde saak en bewoording by semistaatsof staatsorgane en is moontlik vandaar afkomstig. Op sy beurt praat NGKO 1998 besluit 59b2 van 'n persoonlike of finansiële belang by die saak (NGKO 1998:20). Dit dui die belang dus nader aan en laat dit nie oor aan 'n algemene of ' $n$ populêre interpretasie soos in politieke kringe nie.

Om die toon van ' $n$ burgerlike hof te vermy en die pastorale aard van die kerklike tug te verseker, het NGKO 1998 besluit 61b 13.1 bepaal dat ' $n$ aangeklaagde voor ' $n$ NGK-tugliggaam nie geregtig is op 'iemand' wat namens hom/haar optree of hom of haar verteenwoordig nie, maar tog bygestaan kan word deur ' $n$ lidmaat van die eie of ' $n$ ander NGK-gemeente. Bygesê: kerklike tug as ' $n$ pastorale handeling moet voldoen aan die reëls van natuurlike geregtigheid en deur kerkordelike prosedure soek na aanvaarbare persoonlike berou by die skuldige. Dit gaan nie oor 'n regstegniese verdediging én onskuld van die aangeklaagde nie. Die kerklike tughandeling moenie tegnies korrek en juridies-prosedurieel loop nie,

13.NGK 2002 gee die handeling sonder die motivering weer (NGK 2002:295-298 558). Moontlik was die probleem dat die besluite in die praktyk nie as 'voorskriftelik'
beskou is nie. Daarom is dit in die voorwoord van die NGKO 2002 opgeneem dat die beskou is nie. Daarom is dit in die voorwoord van die NGKO 2002
besluite by die Kerkorde ook voorskriftelik is (NGK 2002:293). maar pastoraal, billik en regverdig. Iemand wat ondersoek word, kan iemand anders raadpleeg, maar die ondersoek deur gelowiges van 'n mede-gelowige of gelowiges moenie in 'n kwasi-hofsaak verval nie. Eerlikheid, egtheid en berou en nie regstegniese argumente nie - moet die ondersoek bepaal. Juis daarom is die redes vir NGKO 2013 Reglement 18 punt 8.1.5 wat regsverteenwoordiging van die aangeklaagde(s) deur in die diskresie van die betrokke tugliggaam moontlik maak, duister. Al word dit bepaal deur en beperk tot die moontlikheid dat die aangeklaagde uit sy/ haar kerklike amp/pos ontslaan kan word (NGKO 2011:70, 2013:76). Die moontlike uitvloeisel van 'n kerklike tugsaak moenie tot ' $n$ verjuridisering van sy tughandelinge lei nie.

In NGKO 2015 word die diskresie van die tugliggaam oor die toelating van regsverteenwoordiging vir lidmate wat in dissiplinêre sake of in 'n geval van uitdiensstelling ondersoek word, gehandhaaf. Wat ook by NGKO 2015 insluip, is die gedagte aan ' $n$ tugverhoor en nie ' $n$ kerklike ondersoek nie. Die term 'verhoor' druis immers direk in teen die beginsel van die kerklike tughandeling as ' $n$ pastorale en nie kliniesjuridiese handeling nie (NGKO 2015:81-86; kyk Reglement 18 artikels $2.1-8.1$ ).

Hoewel Reglement 18 van NGKO 2015 meer as vyf bladsye gedetailleerde bepalings bevat (in NGKO 2013 was dit nog vyf), is dit in hierdie stadium nog nodig in die NGK - die lepelbenadering van sekere bepalings ten spyt. Aan die ander kant is daar die probleem dat ' $n$ burgerlike hof in sy hersiening van kerklike tugsake, NGK-vergaderings aan byna vier bladsye kerkorde-artikels en 'n vyfbladsy reglement kan hou en dat hierdie lys meer geleenthede vir hersienbare kerklike prosedurefoute skep. NGKO 2015 se toename van 'n reglement van vier na vyf bladsye op NGKO 2013 laat die gevaarligte van ' $n$ reglementeringswoede in die NGK opnuut flikker (NGKO 2013:73-77, 2015:81-86).

\section{Nederduitse Gereformeerde Kerkorde 2013 en die kerklike tug}

NGKO 2013, in artikels 59 tot 66, handhaaf sy neiging tot nadere, duursame bepalings vir die kerklike tug soos oorgeërf van NGKO 1998. Tog skep sommige punte vrae.

So 'n punt is die invoeging van die verbreking van die diensooreenkoms van besoldigde persone in diens van die gemeente of kerkverband as ' $n$ uitgesonderingsgeval onder die kerklike tug - in NGKO 2013. So asof ' $n$ oortreding van so 'n ooreenkoms ' $n$ spesiale, eiesoortige, aanstootlike sonde is. Die gewigtige voorskrifte in NGKO 2013 artikel 59 vir die uitvoering van die tug soos vervat in die Skrif, die belydenis en die kerkorde, word nou aangevul met die voorskrifte van die bepaalde diensooreenkoms. By die voorskrifte vir die tug geniet die diensooreenkoms as 'n meer regstegniese dokument skynbaar nou gelyke kerklike status met die Woord, die belydenis en die kerkorde. Die vraag is egter: waarom kan enige oortreding in die kerk nie volgens die voorskrifte van die Woord, die belydenis en die kerkorde - in hierdie volgorde van gesag en rang - hanteer word nie? Die 
diensooreenkoms staan in status vér onder die ander drie en hulle - in volgorde - bepaal die voorskrifte vir alle kerklike tughandelinge. Die bytrek van die diensooreenkoms op hierdie punt is 'n Fremdkörper wat uit sy diepte is. ${ }^{14}$ NGKO 2013 artikel 61 en 62 verdiep dié troebel water. Die artikels gebruik 'wangedrag' in terme van 'diensverhoudinge' op dieselfde vlak as sondes wat 'openbare aanstoot' gee - nie daardie gedrag in diensverhoudinge wat ook openbare aanstoot gee nie (NGKO 2013:16). Hierdie feit skep die indruk dat enige verbreking van ' $\mathrm{n}$ diensooreenkoms tugwaardig of aanstootlik is. 'Wangedrag' word ' $n$ nuwe kerkordeterm (van onkerklike oorsprong) wat 'openbare aanstoot' - skynbaar - spontaan in homself omdra. Hierdie waarneming word versterk deur NGKO 2013 artikel 63. Artikel 63.2 stel dit so: 'Kerklike dissiplinêre optrede is die gevolg van - let wel - oortredings by die werkplek en het met die terme van die diensooreenkoms te doen' (NGKO 2013:17). 'Oortredings by die werkplek' word dus ongekwalifiseerd ' $\mathrm{n}$ tugwaardige sonde, dit is 'n openbare, aanstootlike sonde.

NGKO 2013 dra hiermee die letsels van sy verlating van die tipies kerklike pad deur homself teenoor staatsinstellings te probeer verskans deur staatsgeoriënteerde arbeidswetlike reëlings oor te neem sonder ' $n$ kerklike verinheemsing daarvan. 'n 'Onkerklike' huweliksluiting wat innerlike spanning en teenstrydighede meebring.

Op die sukses van NGKO 1998 om 'nadere en duursame' reëlings vir die kerklike tug te tref, is reeds gewys. Ook op die feit dat NGKO 2013 hierdie kerkorde-artikels in hulle kern oorgeneem het en nog dra. Nuwe ontwikkelinge word in NGKO 2013 gereflekteer, soos die sensuur oor dooplidmate wat hulle die reg om die nagmaal te gebruik, ontneem. Onnodige detail kom voor in artikel 66.3.2 wat bepaal dat kerkraadslede wat weens tugmaatreëls die amp moes ontruim, by die opheffing hiervan weer verkiesbaar is. Opheffing van tugmaatreëls op belydende lidmate of, dan, die geval van ' $n$ belydende lidmaat wat nie (of nie meer nie) onder tug is nie, maak so 'n iemand natuurlik vir die kerkraad verkiesbaar. Hierdie onnodige bepaling is ' $n$ teken van die neiging tot detail by sommige outeurs van NGKO's.

\section{Slotbevinding}

NGKO 2013 dra die spore van meer as een benadering tot die kerklike tug deur die Algemene Sinode van die NGK sedert die ontstaan daarvan in 1962.

Aan die een kant handhaaf sy artikels 59 tot 66 oor die algemene uitgangspunte van die kerklike tug, oor tugwaardige sondes, wie onder tug kan kom, tug- en dissiplinêre maatreëls en die opheffing van hierdie maatreëls nadere en duursame bepalings. Hierin is hy duidelik kerkordelik gereformeerd. Die Algemene Sinode van 1998

14.In die NGK en NGKO is die Bybel die belyde opjekti................................. daar nie verskil nie. Die aanvaarding van die belydenisskrifte en die kerkorde vereis by verskillende kerkvergaderings ' $n$ tweederde meerderheid terwyl die diensooreenkoms van ' $n$ kerkvergadering met ' $n$ persoon of persone deur ' $n$ diensooreenkoms van " $n$ kerkvergadering met ' $n$ persoon of persone deur ' $n$
gewone meerderheid van hierdie vergadering aanvaar word (NGKO 2013:12 artikel gewone m 45 ) het met hierdie artikels ' $n$ nuwe tydvak in die NGK oor die tughandeling ingelei. Sy bepalings het aan tugvergaderings speelruimte gegee om met die Bybel in die hand en gebonde aan hierdie artikels liefdevol, regverdig en medemenslik op te tree. Om die sondaar of aangeklaagde met die tug nader te trek en te bind. Om op hierdie manier die orde en welsyn van die gemeente én die kerkverband te bevorder.

Daarmee het die Algemene Sinode van die NGK positief geantwoord op die probleemstelling van hierdie artikel.

Aan die ander kant trap NGKO 2013 (en ook NGKO 2011 en 2015) met sommige subartikels en sy Tugreglement in die strik om detailvoorskrifte te gee wat hierdie speelruimte vernou. Dit gee daarby geen aanduiding dat sy meer gedetailleerde Tugreglement net noodsaaklike, tydelike oorgangsmaatreëls bevat nie - maatreëls wat as oorgangsmaatreëls vervat is in NGKO 1998. Terselfdertyd is NGKO 2013, soos van sy voorgangers, sigbaar sensitief vir staatswette en die eise wat dit aan die NGK as kerk stel. Hierdie bewussyn laat dit byna semi-staats oor - veral - sy sogenaamde dissiplinêre aangeleenthede dink.

'n Karaktertrek van die Algemene Sinode van die NGK in sy bepalings vir die kerklike tug van 1962 tot 2013, is sy gebrek aan bestendigheid. Nie net skipper hy rond tussen die aanvaarding of skrapping van 'n tugreglement nie, maar sy benadering tot die tug wissel ook. In NGKO 2013 word dit gesien in sy onderskeid tussen tug en dissipline. NGKO 2013 handhaaf laasgenoemde as ' $n$ afsonderlike 'genre' onder die kerklike opsig en tug. 'n Onderskeid wat nie werklik nodig is nie, maar 'n oor het vir formele dienskontrakte as 'n uitvloeisel van nuwe arbeidswetgewing ná 1994 in Suid-Afrika.

Hierdie artikel kan met ' $n$ behoorlike gevallestudie van die tughandeling in die NGK verryk word. So 'n stuk kan op meer as net die NGKO en sy bepalings en tendense konsentreer.

\section{Erkenning}

\section{Mededingende belange}

Die outeur verklaar dat hy geen finasiële of persoonlike verbintenis het met enige party wat hom nadelig kon beinvloed in die skryf van hierdie artikel nie.

\section{Befondsing}

Universiteit van die Vrystaat namens Navorsingsgenoot P.J. Strauss, Departement van Historiese en Konstruktiewe Teology, Fakulteit van Teologie.

\section{Literatuurverwysings}

\footnotetext{
Bouwman, H., 1985, Gereformeerd Kerkrecht II, Kok (Derde onveranderde druk), Kampen.

De Jong, O.J., 1987, Geschiedenis der kerk, Callenbach, Nijkerk.

Jonker, W.D., 1960, 'Die bevoegdheid van die streeksinodes in die nuwe konsepkerkorde van die Ned Geref Kerk', NGTT Maart 1960, 33-37.

Jonker, W.D., 1965, Om die regering van Christus in sy kerk, Unisa, Pretoria.
} 
Kleynhans, E.P.J., s.a., Die kerkregtelike ontwikkeling van die Ned Geref Kerk in SuidAfrika 1795-1962, s.l., s.n.

Koffeman, L.J., 2009, Het goed recht van de kerk, Kok, Kampen.

Kruger, L.S., Du Plessis, H.L.M., Spoelstra, B. \& Spoelstra, T., 1966, Handleiding by die Kerkorde van die Gereformeerde Kerk in Suid-Afrika, Pro Rege, Potchefstroom.

Nauta, D., 1971, Verklaring van de Kerkorde van de Gereformeerde Kerken in Nederland, Kok, Kampen.

Ned Geref Kerk, 1857, Handelingen van de Algemene Synode van de Nederduitsch Gereformeerde Kerk van Zuid-Afrika 1824, 1826, 1827, 1834, 1837, 1842, 1847, Gereformeerde Kerk van Zuid-Afrika
Van de Sandt De Villiers, Kaapstad.

Ned Geref Kerk (NGKO), 1964, Kerkorde van die Ned Geref Kerk 1962, NG KerkUitgewers, Kaapstad.

Ned Geref Kerk (NGKO), 1970, 1974, Die Kerkorde, NG Kerkboekhandel, Pretoria.

Ned Geref Kerk (NGKO), 1994, 1998, Die Kerkorde, Hugenote-Uitgewers, Wellington. Ned Geref Kerk (NGKO), 2002, 2004, Die Kerkorde, Lux Verbi.BM, Wellington.

Ned Geref Kerk (NGKO), 2007, Die Kerkorde, Bybelmedia, Wellington.

Ned Geref Kerk (NGKO), 2011, 2013, 2015, Die Kerkorde, s.I., s.n.

Ned Geref Kerk in die Vrystaat (NGKO VS), 1998. Die Kerkorde, s.l., s.n.

Ned Geref Kerk III, 1982, Die drie formuliere van eenheid en ekumeniese belydenisse, NG Kerk-Uitgewers, Kaapstad.

Plomp, J., 1969, De kerkelijke tucht bij Calvijn, Kok, Kampen.
Plomp, J., 1992, 'Kerk en recht', in W. Van't Spijker \& L.C. Van Drimmelen (eds.), Inleiding in de studie van het kerkrecht, pp. 32-42, Kok, Kampen.

Pont, A.D., 1981, Die historiese agtergronde van ons kerklike reg, HAUM, Pretoria.

Pont, A.D., 1991, Die historiese agtergronde van ons kerklike reg II, Kital, Pretoria.

Rutgers, F.L., 1971, De geldigheid van de oude kerkenordening der Nederlandsche gereformeerde kerken, Ton Bolland, Amsterdam.

Sadler, T.H.N., 1979, Die kerklike tughandeling, NG Kerkboekhandel van Transvaal, Pretoria.

Smit, C.J., 1984, God se orde vir sy kerk, NG Kerkboekhandel van Transvaal, Pretoria. Spoelstra, B., 1989, Gereformeerde kerkreg en kerkregering, GKSA, Hammanskraal. Strauss, P.J., 2001, 'Kerkverband in die NG Kerk vandag', NGTT 42/3 en 4, 395-405.

Strauss, P.J., 2008a, 'Die 'kerklike gesag' van kerkvergaderings soos in die Kerkorde van die Ned Geref Kerk', In die Skriflig 42/2, 239-252. https://doi.org/10.4102/ids. v42i 2.266

Strauss, P.J., 2008b, ‘Die NG Kerkorde - 1962: Die Dordtse kerkorde aangepas by die eise van die dag?', NGTT 49/3 en 4, 274-285.

Strauss, P.J., 2009, 'Kerkreg, 'n dienende reg?', NGTT 50/3 en 4, 492-499.

Strauss, P.J., 2010, Kerk en orde vandag - met die klem op die NG Kerk, SUN Media, Bloemfontein.

Van der Linde, G.P.L., 1983, Die Kerkorde, TG van Wyk, Pretoria.

Visser, J., 1999, Die Kerkorde in praktyk, EFJS, Orkney. 